\title{
Diversification of Capabilities of Economies in the Field of Talent Management. Poland Against the Background of the European Union
}

\author{
Ph.D Monika Sipa ${ }^{1}$
}

\begin{abstract}
:
Among the dilemmas of contemporary enterprises, regions and economies, there is a growing shortage of talent. The demand of the economies and enterprises for specific skills, competences and knowledge that shape their innovativeness and competitiveness is related to the responsible and sustainability human capital management. Attracting and optimizing human capital, which contributes to increasing productivity and prosperity of economies, requires appropriate potential that is built by thought-out and long-term activities within their policies. Therefore, the main objective of the study was to identify changes within the potential of the Polish economy in the context of talent management and to identify areas in which the largest differences are visible in relation to the average of the European Union. The assumptions and data from the Global Talent Competitiveness Index (GTCI) and the European Innovation Scoreboard (EC) were used in the research. The data from the years 2013-2018 were analyzed, with particular focus on skills, on the medium and high level (the output sub-index): Vocational and Technical Skills and Global Knowledge Skills.
\end{abstract}

Key words: EU countries, GTCI, talent management, sustainable development, buman capital.

\section{Introduction}

The changes taking place on the global market, related among other things to the increasing mobility of societies, fast technological development, demographic changes, create a new reality in which a more extensive approach towards human potential is necessary (ManpowerGroup, 2016; Skibiński, Rączaszek, 2017). The development of new technologies means that the structure of the labor market is changing - whole sectors of activity are transformed, as well as the nature of the work itself. There are enormous changes in jobs requiring low and medium qualifications and highly qualified employees (Lanvin, Evans, 2017).

Unfavorable demographic changes, as well as aging population and low unemployment rate make it increasingly difficult for entrepreneurs to obtain employees with specific skills and competences. It also results from discrepancies between supply and demand for specific resources of talented employees, in specific places and time. Therefore, the biggest challenge for entrepreneurs and economies is the increasing talent gap (Mazurkiewicz, 2013; ManpowerGroup, 2016; Sipa, Skibiński, Gorzeń-Mitka, 2016). As Michaels and others (2001) point out, the change in the approach to talent management is determined by the conditions in which modern enterprises operate. 
At present, the talent shortage is already noticeable in many regions and sectors of the economy, which may prove to be dangerous for global economic growth (in Japan, shortage of talent is perceived by $86 \%$ of employers (ManpowerGroup, 2018). Global skills and the level of talent management implementation depend to a large extent on the basic social processes and the level of remuneration. This is particularly evident in the case of developing countries, of which are the most frequently suffering from drainage of talents to highly developed economies (Serbana, Andanuta, 2014). Individual countries must determine how emerging deficiencies can be supplemented on a regular basis and how to avoid further widening of the talent gap.

This problem also affects entities operating in economies, whose socio-economic transformation began only at the beginning of the 1990s, such as Poland. The integration of Poland with the European Union in 2004 and the EU cohesion policy enabled development, building the innovation potential as well as the easier flow of knowledge (Barska, Jędrzejczak-Gas, Wyrwa, 2017; Smolarek, Sipa, 2017). In recent years, the talent gap phenomenon has intensified. In Poland, this is particularly visible from 2013, when $32 \%$ of entrepreneurs reported problems with finding employees with appropriate skills, and in 2018, 51\% of entrepreneurs indicated shortage of talents (ManpowerGroup, 2018)

Individual countries adopt different strategies for developing and maintaining talents. The result of these activities is that some countries are masters of talents and others are weak employees (Lanvin, Evans, 2013).

In connection with the above, the basic objective of the study was to identify changes within the potential of the Polish economy in the context of talent management and to identify areas in which the largest differences are visible in relation to the average of the European Union. The assumptions and data from the Global Talent Competitiveness Index (GTCI) and the European Innovation Scoreboard (EC) were used in the research. The directions of changes within the analyzed variables were also indicated, with special attention being focused on skills, at an average and high level (output sub-index): Vocatinal and Technical Skills (V\&T) and Global Knowledge Skills (GK).

\section{Talent management problem - a brief literature review}

There are many publications in literature addressing the problem of talent management in various areas, emphasizing, among other things, its significance in terms of strengthening innovation and building a sustainable competitive advantage (Makela, Bjorkman, Ehrnrooth, 2010; Skuza, Scullion, McDonnel, 2013). Changing environment and new conditions, creating a new reality in which business entities must function and develop, make it necessary to further penetrate this issue.

Talent is an indispensable source of knowledge, development; it creates a strong foundation for competitive struggle, constituting a source of innovative and creative solutions for organizations and economies (It is a resource with above-average skills and knowledge, ready for new challenges and involved in the work performed (ManpowerGroup, 2008). Highly qualified human resources create a knowledge base for the company, which is a source of ideas for new products and processes (Mohnen, Roller, 2005). They can lead to the creation of more efficient technologies and are 
necessary for increasing the innovativeness of entities (Navickas, Kontautiene, 2013). Employee talents determine above-average effectiveness in the implementation of job functions. They support and set organizational goals and enable a company to react quickly to the pressure of market competition (Jabłoński, 2015). They also affect the shape and quality of other human resources (Buchelt, 2016).

Employee talents are a category that includes the characteristics of the organization's members, guaranteeing the achievement of exceptional results at workplaces. They are partially innate and partly acquired throughout life (Jabłoński, 2015). According to Chartered Institute of Personnel and Development (CIPD) (2007), defining talents depends on: the specifics of the organization, the type of industry and the nature of the work and its dynamics, which means that they can change over time according to the organization's priorities.

Problems related to the future demand of economies for specific skills, competences and knowledge (shaping their innovativeness and competitiveness), force entrepreneurs to change the current approach to employee management. Governments, enterprises and other organizations interested in talent management need quantitative tools, informing about the actions taken and supporting the design and implementation of appropriate policies, for example in the field of education, employment or migration (Gorzen-Mitka, 2016; Lanvin, Evans, 2016; Okręglicka, et al, 2017). Only in this way can continuity be planned for talented employees on key positions that "carry" innovative actions (Turner, Tansley, Foster, Harris, Stewart, Sempik, Williams, 2007). As Serban and Andanut (2014) pointed out, „on an national level, talent management should provide a long term approach regarding integrated actions that lead to creating and retaining those talents in the inside borders." In order to increase their competitiveness and innovativeness in the global world, economies must support organizations operating within it, creating an environment conducive to conducting innovative activity, attracting and maintaining adequate potential, in the form of highly qualified human and financial resources that may lead to more efficient technology (Navickas, Kontautiene, 2013; Sitek, 2017).

Tupa (2013) emphasizes that business leaders know that distinctive, advanced talent management is necessary to build short and long-term innovation abilities necessary to realize innovative golas. As pointed Pachura (2017) ,... that what underlies the building of the state of "optimal readiness" of an organisation for changes and innovation is recognition of an employee, friendly organisational environment and development of interpersonal relations". Managers point to a clear relationship between the work of talents and the qualitative and financial effects of their projects Buchelt , 2016).

Talent management is a complex and continuous process. It is based on the systematic attraction, identification, development, retention and exploitation of people with high potential, who are particularly valuable (Turner, et al, 2007). At the macroeconomic level, talent management is associated with activities aimed at increasing the quality of general and vocational education, introducing strategies for migration, activating people who have been inactive in the labor market so far and maintaining older, but qualified and experienced employees in the organization (ManpowerGroup, 2016).

The basic strategy for talent management is to search for, define and cultivate the skills that will be needed to maintain the future competitive advantage (Frank, Taylor, 2004). In the strategic approach to the talent management process, the level of interaction 
between employers and employees or their representatives is very important, as is the compatibility of employees' interests with the interest of the company (Ścibiorek, 2004; Sullivan i al., 2010). Entrepreneurs should take care to become the target place for their employees for their talents (ManpowerGroup, 2016).

\section{Methodology}

The study included quantitative data describing the importance of talent and its impact on the competitiveness of countries in the form of the Global Talent Competitiveness Index (GTCI). Reference was also made to the data defining the level of innovativeness of economies, via the Summary Innovation Index (SII). The main source of data were the "The Global Talent Competitiveness Index" Reports. Data from the "Regional Innovation Scoreboard" was also used. The analysis covered indicators from the years 2013-2018. The GTCI index is generated by using over 45 benchmarking indicators, which was collected on two levels: input and output. The input sub-index is determined by institutional enablers for talent development, also other means to attract, grow and retain talent. The output sub-index, evaluates Global Knowlage and Labour\&Vocational skills.

The main objective of the research was to identify changes taking place within the potential of the Polish economy in the context of talent management and to identify areas in which the largest differences are visible in relation to the average of the European Union. The directions of changes within the analyzed values were also indicated and an attempt was made to determine the position of Poland within the group of EU countries.

On the basis of the collected data, a comparative analysis was carried out, which took into account the situation in Poland and the European Union. In the case of GTCI (Lanvin, Evans, 2013, 2014, 2015, 2016, 2017), in order to obtain a benchmark, the EU average was calculated on the basis of the results of individual members of the European Union, which was referred to in the research section.

\section{Results}

Poland belongs to the economies of Europe, which are derived from the "former Eastern Bloc" and in which the process of socio-economic transformation has been going on since the early 1990s, and since 2004 are members of the European Union. As emphasized earlier, appropriate talent potential is necessary to increase the innovativeness of economies, and talent-specifying skills require innovative economy and good education.

Observing the value of the Innovation Index (SII), it can be seen that the level of innovation in the Polish economy still leaves much to be desired.

In 2013-2017, the increase in the SII index is visible, but these are very small changes. Poland still ranks near the end of the ranking. The dynamics of SII for Poland equal 108.95, while for the EU - 105.86 (European Commision, EIS 2018 database).

Taking into account the Summary Innovation Index (SII), small grow value can be noted in the level of innovation in Polish economie. It can also be noted that for all the years 
studied, the Poland had the values of SII far from the average for the EU. Poland belong to a category of countries known as "Moderate innovators" and it is in the penultimate position among the "Moderate innovators". The group includes Member States where performance is between $50 \%$ and $90 \%$ of the EU average.(moree: Sipa, 2015)

Analyzing the data from the reports of "The Global Talent Competitiveness Index" for the years 2013-2018, Poland's relatively weak position against the background of other European Union countries is noticeable. According to the rankings, the GTCI index for Poland in all examined years is lower than the average of countries belonging to the European Union. In the analyzed years, average GTCI values for the EU oscillate from 55.02 to 59.20, while the number of GTCI points for Poland - from 49.11 to 53.29. The successively increasing difference between these values is also visible. Poland, according to rankings from 2013-2018, is in the top ten of the European Union members. This position, unfortunately, is not improving. (fig.1)

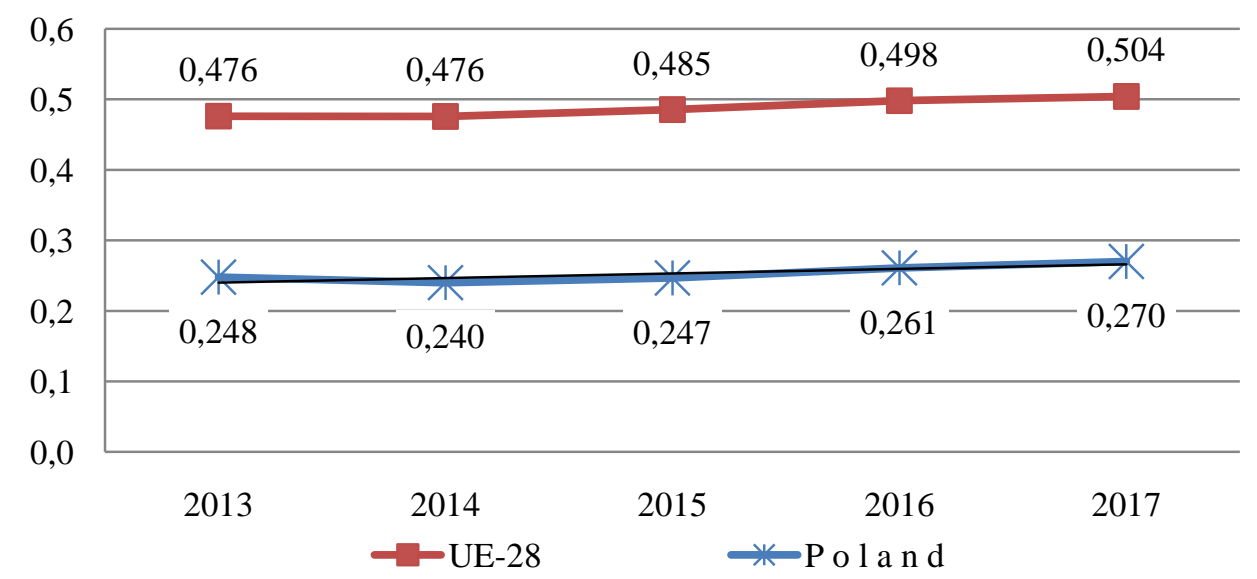

Figure 1. European Innovation Scoreboard 2014-2017 - SII time series

Source: European Commision, European Innovation Scoreboard (2014-2018); https:/ / ec.europa.eu/growth/industry/innovation/facts-figures/scoreboards_en (28.07.2018)

Looking at the changes in the GTCI index in the analyzed period, one can notice the fluctuations of points awarded by experts. This indicator, both for Poland and the EU, received a lower score after 2013. In the case of the EU, in 2014 and 2015/16, a further decline in scores is visible, but in subsequent years it has reached higher values, and the dynamics of changes compared to 2013 amounted to 103.14. (tab.1)

In turn, Poland, according to the rankings from the years 2014 and 2015/16, improved the scores, but in 2018 the rating was again lower and it failed to reach the level of scoring from 2013. Among the EU members, the highest scores in the ranking are most often obtained by: Sweden, Finland and Denmark. There is a significant distance visible in case of Poland in relation to the ratings obtained by the leading EU countries. According to the Report from 2018, GTCI for Sweden was 74.32, Finland 73.32, and Denmark 73.79 . 
in case of more detailed assessments, reference was made to changes within two GTCI sub-indexes: input and output. According to experts, a higher grade is received by the input sub-index (pillars: Enablers, Attract, Grow and Retain).

Table 1. GTCI for Poland and UE

\begin{tabular}{|l|l|l|l|l|l|l|l|l|}
\hline & $\mathbf{2 0 1 3}$ & $\mathbf{2 0 1 4}$ & $\begin{array}{l}\mathbf{2 0 1 5} \mathbf{6} \\
\mathbf{6}\end{array}$ & $\mathbf{2 0 1 7}$ & $\mathbf{2 0 1 8}$ & $\mathbf{m i n}$ & $\mathbf{m a x}$ & $\begin{array}{l}\text { Dynamics } \\
\mathbf{2 0 1 3 = 1 0 0}\end{array}$ \\
\hline UE Average & 57.40 & 55.20 & 55.02 & 58.69 & 59.20 & 55.02 & 59.20 & $\mathbf{1 0 3 . 1 4}$ \\
\hline Poland vU & 53.29 & 49.11 & 52.08 & 52.32 & 50.06 & 49.11 & 53.29 & $\mathbf{9 3 . 9 4}$ \\
\hline $\begin{array}{l}\text { Poland vs EU } \\
\text { difference } \\
\text { (points) }\end{array}$ & $\mathbf{- 4 . 1 1}$ & $\mathbf{- 6 . 0 9}$ & $\mathbf{- 2 . 9 4}$ & $\mathbf{- 6 . 3 7}$ & $\mathbf{- 9 . 1 4}$ & - & - & - \\
\hline
\end{tabular}

Source: done by author on the basis of "The Global Talent Competitiveness Index",The raports 2013-2018; https:/ /gtcistudy.com/ (15.07.2018)

In the case of input sub-index, the lowest value was indicated in "The Global Talent Competitiveness Index" 2015/16. This applies to both the Polish economy (50.11) and the average for EU countries (58.06). It can be noticed, however, that the GTCI input sub-index for the EU since 2014 has been gradually increasing, and the dynamics in the analyzed period amounted to $102.25(2013=100)$. Unfortunately, such positive changes cannot be observed in the case of the Polish economy. The chain analysis shows that after slight increases in the score in 2015/16 and 2017, in the report from 2018, this indicator (Input sub-index) was rated lower by experts (52.15). As a result, Poland lost 4.09 points in relation to 2013 and loses 10.79 points in 2018, as compared to the EU average (in 2013 it was 5.31). The discrepancy between the values of indicators for Poland and the EU has increased over the years - almost two times. (tab.2)

Table 2. The changes GTCI input sub-index (2013-2018)

\begin{tabular}{|l|l|l|l|l|l|l|l|l|}
\hline & $\mathbf{2 0 1 3}$ & $\mathbf{2 0 1 4}$ & $\begin{array}{l}\mathbf{2 0 1 5 / 1} \\
\mathbf{6}\end{array}$ & $\mathbf{2 0 1 7}$ & $\mathbf{2 0 1 8}$ & $\mathbf{m i n}$ & $\mathbf{m a x}$ & $\begin{array}{l}\text { Dynamics } \\
\mathbf{2 0 1 3}=\mathbf{1 0 0}\end{array}$ \\
\hline EU Average & 61.55 & 58.06 & 60.74 & 61.14 & 62.94 & 58.06 & 62.94 & $\mathbf{1 0 2 . 2 5}$ \\
\hline Poland ve E & 56.24 & 50.11 & 54.05 & 54.95 & 52.15 & 50.11 & 56.24 & $\mathbf{9 2 . 7 3}$ \\
\hline $\begin{array}{l}\text { Poland vs } \\
\text { difference } \\
\text { (points) }\end{array}$ & $-\mathbf{5 . 3 1}$ & $\mathbf{- 7 . 9 6}$ & $\mathbf{- 6 . 7 0}$ & $\mathbf{- 6 . 1 9}$ & $\mathbf{- 1 0 . 7 9}$ & - & - & - \\
\hline
\end{tabular}

Source: done by author on the basis of "The Global Talent Competitiveness Index",The raports 2013-2018; bttps://gtcistudy.com/ (15.07.2018)

The GTCI input sub-index is based on four pillars: Enablers, Attract, Grow and Retain. (tab. 3) Looking at the assessment of individual areas, both for Poland and the EU, the division of these pillars into two groups can be noticed. The highest rated in the analyzed years were two categories: Enablers and Retain. Attract and Grow had received fewer points.

Regarding the volumes describing the EU, it can be noted that compared to 2013, there was an improvement in the expert assessment only in the case of Enablers and Retain the most visible in the case of Retain. It is also the area that recorded the greatest 
improvement in the assessment in the analyzed years. Data indicates that in 2018 the points awarded increased by almost 14\%, as compared to 2013. Looking at the average for individual values in the analyzed years, a slightly higher score is visible for Enablers, however the report from 2018 indicates Retain as the area with the highest rating (73.17) and the dynamics of 113.94.

The Attract and Grow pillars had received lower scores. Taking the year 2013 as a basis, the average EU rating is lower by 3.89 for Attract and 1.63 point for Grow.

Similarly to the average of the European Union, in the case of Poland, the highest rated categories in the analyzed years were: Enablers and Retain. The number of points granted oscillates around 60 points (from 57.46 to 62.77 - Enablers and from 54.38 to 64.71 for Retain). The highest rating in the audited period concerns Enablers. Attract and Grow are rated lower, with a score of no more than 50 points in recent years (maximum is 50.68 points). The area of Attract was assessed as the lowest, which may mean that Poland seems to be unattractive to talent. Lack of improvement in this area may result in further drainage of talents, especially in the areas of specialist skills and competences. A higher assessment of the country's policy and resources creating a climate for talents (regulatory landscape; Market landscape; biznes-labour landscape) or maintaining talents may be insufficient if the remaining elements (attract $\mathrm{i}$ grow) are assessed lower. Unfortunately, the grades awarded in 2018 in all four pillars are lower than in 2013.

Table 3.The main pillars in GTCI input sub-index (2013-2018)

\begin{tabular}{|c|c|c|c|c|c|c|c|c|c|}
\hline \multicolumn{2}{|c|}{ Pillars } & 2013 & 2014 & $2015 / 16$ & 2017 & 2018 & $\min$ & $\max$ & $\begin{array}{l}\text { Dynamics } \\
2013=100\end{array}$ \\
\hline \multirow[b]{4}{*}{ 只 } & Enable & 64.69 & 64.48 & 65.94 & 66.23 & 66.82 & 64.48 & 66.82 & 103.29 \\
\hline & Attract & 58.42 & 54.27 & 55.93 & 56.59 & 54.53 & 54.27 & 58.42 & 93.34 \\
\hline & Grow & 58.86 & 54.51 & 53.64 & 58.13 & 57.23 & 53.64 & 58.86 & 97.23 \\
\hline & Retain & 64.22 & 58.98 & 67.46 & 63.59 & 73.17 & 58.98 & 73.17 & 113.94 \\
\hline \multirow{4}{*}{ 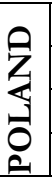 } & Enable & 62.77 & 57.46 & 62.74 & 62.02 & 60.51 & 57.46 & 62.77 & 96.40 \\
\hline & \begin{tabular}{|l|} 
Attract \\
\end{tabular} & 50.31 & 40.60 & 44.27 & 46.58 & 42.87 & 40.60 & 50.31 & 85.21 \\
\hline & Grow & 48.11 & 47.98 & 44.46 & 50.63 & 45.78 & 44.46 & 50.63 & 95.16 \\
\hline & Retain & 63.76 & 54.38 & 64.71 & 60.55 & 59.43 & 54.38 & 64.71 & 93.21 \\
\hline
\end{tabular}

Source: done by author on the basis of "The Global Talent Competitiveness Index",The raports 2013-2018; bttps://gtcistudy.com/ (15.07.2018)

Looking at the dynamics of changes in expert assessments, it can be noticed that the grade increases are very low and even that not in all areas. There is an observable lack of stability and improvement in the studied areas. Unfortunately, compared to 2013, the Polish economy obtained a lower score in each of the areas, which was not without significance for the average score for the EU. As in the case of the EU average - Attract is the lowest-graded of the four pillars.

Input sub-index is rated higher than the GTCI output sub-index. The output sub-index includes two pillars: Vocational and Technical Skills and Global Knowledge Skills, which aim to describe and measure the quality of talent in the country. As Buračas and Navickas (2015) point out, there are interactions between these skills and innovation and 
competitiveness of economies. Talent-defining skills require an innovative economy and good education, while a higher level of skills allows to expect adequately higher abilities to increase the economic potential, greater innovation and high quality of education. (tab. 4)

The average score of GTCI output sub-indexes for the EU is increasing from year to year, while in 2018 it reaches a slightly lower result as compared to the previous year, by 0.09 points. However, assuming 2013 as the base year, there is a positive dynamics of this result - 105.35. Unfortunately, in the case of Poland, the output sub-indexes of GTCI, in the years 2013-2016, increased to 48.17; however, in subsequent reports, this area was graded significantly lower. According to the experts' assessment, the output sub-indexes of GTCI in 2018 gained 45.90 points, which is the lowest assessment in the analyzed years. In relation to the value from 2013, there was a decrease of 1.51 point.

The differences between the EU's output sub-index and Poland are not as large as in the case of the input sub-index. Over the years, however, the increasing distance between Poland and the EU average becomes visible. This is particularly noticeable since 2017. Differences in ratings increased from 1.71 points in 2013 to 5.85 in 2018.

Table 4.The changes GTCI output sub-index (2013-2018)

\begin{tabular}{|l|l|l|l|l|l|l|l|l|}
\hline & $\mathbf{2 0 1 3}$ & $\mathbf{2 0 1 4}$ & $\mathbf{2 0 1 5 / 1 6}$ & $\mathbf{2 0 1 7}$ & $\mathbf{2 0 1 8}$ & $\mathbf{m i n}$ & $\mathbf{m a x}$ & $\begin{array}{l}\text { Dynamic } \\
\text { s 2013=100 }\end{array}$ \\
\hline UE Average & 49.12 & $\mathbf{4 9 . 4 6}$ & 50.66 & 51.83 & 51.74 & 49.12 & 51.83 & $\mathbf{1 0 5 . 3 5}$ \\
\hline Poland & 47.41 & $\mathbf{4 7 . 1 2}$ & $\mathbf{4 8 . 1 7}$ & 47.08 & 45.90 & 45.90 & 48.17 & $\mathbf{9 6 . 8 1}$ \\
\hline $\begin{array}{l}\text { Poland vs EU } \\
\text { difference } \\
\text { (points) }\end{array}$ & $\mathbf{- 1 . 7 1}$ & $\mathbf{- 2 . 3 4}$ & $\mathbf{- 2 . 4 9}$ & $\mathbf{- 4 . 7 5}$ & $\mathbf{- 5 . 8 5}$ & - & - & - \\
\hline
\end{tabular}

Source: done by author on the basis of "The Global Talent Competitiveness Index",The raports 2013-2018; bttps://gtcistudy.com/ (15.07.2018)

Output sub-index GTCI form the two pillars of Vocational and Technical Skills and Global Knowledge Skills.(tab. 5) Unfortunately, looking at the analyzed years, the Polish economy scores low. Only in the case of Vocational and Technical Skills, in the rankings for the years 2014-2017, Poland obtained a higher rating than the EU average; however, according to the last ranking in 2018, the assessment of this figure decreased compared to the previous year and reached a lower level, as the EU average. There is an observable lack of consistency and stability within the objectives pursued by Poland. The dynamics of changes compared to 2013 showed that in the VT area, the increase in scores is visible; however, in Poland the dynamics are lesser (117.11) than in the case of the EU average (119.56). Declines within the GK are consistent. For Poland, it was $23.58 \%$ and for the EU, 8.87\%.

Quite low scores within the Capital Group and negative dynamics in this area are quite disturbing. As indicated by Buračas and Navickas (2015), this pillar brings together the most sensitive identifiers that directly determine the professional ability of potential talents. We have, among others, sub-pillar High-Level Skills, Mid-Level Skills, Employability and Talent Impact. 
Table 5.The main pillars in GTCI output sub-index (2013-2018)

\begin{tabular}{|l|l|l|l|l|l|l|}
\hline \multicolumn{2}{|l|}{ Vocational \&Technical Skills } \\
\hline & $\mathbf{2 0 1 3}$ & $\mathbf{2 0 1 4}$ & $\mathbf{2 0 1 5 / 1 6}$ & $\mathbf{2 0 1 7}$ & $\mathbf{2 0 1 8}$ & $\begin{array}{l}\text { Dynamics } \\
\mathbf{2 0 1 3}=\mathbf{1 0 0}\end{array}$ \\
\hline UE & 49.14 & 54.88 & 54.97 & 58.67 & 58.75 & $\mathbf{1 1 9 . 5 6}$ \\
\hline Poland & 47.52 & 57.28 & 60.95 & 59.63 & 55.65 & $\mathbf{1 1 7 . 1 1}$ \\
\hline $\begin{array}{l}\text { Poland vs EU } \\
\text { difference (points) }\end{array}$ & $\mathbf{- 1 . 6 2}$ & $\mathbf{2 . 4 0}$ & $\mathbf{5 . 9 8}$ & $\mathbf{0 . 9 6}$ & $\mathbf{- 3 . 1 0}$ & - \\
\hline \begin{tabular}{l} 
Global Knowledge Skills \\
\hline
\end{tabular} & $\mathbf{2 0 1 3}$ & $\mathbf{2 0 1 4}$ & $\mathbf{2 0 1 5 / 1 6}$ & $\mathbf{2 0 1 7}$ & $\mathbf{2 0 1 8}$ & $\begin{array}{l}\text { Dynamics } \\
\mathbf{2 0 1 3}=\mathbf{1 0 0}\end{array}$ \\
\hline $\begin{array}{l}\text { EU Average } \\
\text { Poland }\end{array}$ & 49.09 & 44.04 & 46.35 & 44.99 & 44.73 & $\mathbf{9 1 . 1 3}$ \\
\hline $\begin{array}{l}\text { Poland vs EU } \\
\text { difference (points) }\end{array}$ & $\mathbf{- 1 . 8 0}$ & $\mathbf{- 7 . 0 8}$ & $\mathbf{- 1 0 . 9 7}$ & $\mathbf{- 1 0 . 4 7}$ & $\mathbf{- 8 . 5 9}$ & - \\
\hline
\end{tabular}

Source: done by author on the basis of "The Global Talent Competitiveness Index",The raports 2013-2018; bttps://gtcistudy.com/ (15.07.2018)

In summary, it can be seen that in all years the assessment of individual pillars within the output sub-index GTCI for Poland is lower than for the EU. Only in 2014-2017 and only in the case of VT, the indication for Poland was not much higher. This situation may mean that the level of Polish potential does not positively affect the result describing the European Union. Rather, it is formed by the evaluations of countries such as: Finland (65.13), Sweden (62.95), Denmark (62.95) - (data from 2018).

\section{Conclusion}

The "war" for talents takes on a strategic dimension, becoming nowadays a necessary element of increasing knowledge and innovation of economies and the entities operating within them. Awareness of the changes taking place puts the economies at the forefront of strategic thinking about reducing the talent gap. Long-term activities are required, aimed at developing and reducing the outflow of existing talent resources and attracting new ones.

Poland still has much to do in the area of talent management. The low level of innovation and the lack of improvement in the assessment of talent management will not help in building an innovative and competitive economy. Poland is an economy that has difficulties in talent retention due to the proximity of countries that offer greater opportunities and attract talent from countries with weaker potential. According to data analysis, the gap between the assessment for Poland and the EU average is visible in all the areas studied. Poland in all GTCI rankings ranked in the top ten (38/39, 32 in 2013), while among EU members in the second ten (18/21/22/23 - most recently 22).

When comparing input and output sub-indexes, it can be noticed that the values for output parameters are lower in all analyzed years than inputs, and the values of indirect indicators are lower for Poland than the average for the European Union. As part of the 
two main pillars, stratification in relation to the EU average is most visible for the GTCI input sub-index. The difference increased from 5.31 to 10.79 points. In the analyzed years, the negative dynamics is visible in almost all Polish GTCI pillars. Positive dynamics apply only to VT within the output sub-index.Particular attention should be focused on undertaking actions strengthening the areas included in the GTCI output sub-index. The average European Union GTCI output sub-index score, according to most rankings, is higher than the ratings given to Poland. This applies in particular to variables within: Global Knowledge Skills, ie: High level Skills and Talent Impact.

According to experts, the higher grade is granted to the sub-index input; however, it is necessary to improve such pillars as: Attract, Grow. Attention should also be paid to Retain, which, despite higher expert ratings (in relation to Attract and Grow), increased its distance in relation to the EU average. In 2013, the difference was 0.46 point and according to the Report of 2018, the assessment of this area is lower for Poland by 13.73.

Summing up, it should be emphasized that the presented analysis is only an outline of the situation regarding the issues of innovation and talent management of the economies studied. However, it is a starting point for further research, taking into account other variables and interrelations between them.

\section{References}

Barska A., Jędrzejczak-Gas J., Wyrwa J. (2017). Innovative activity of the enterprises in the service sector in Poland, in: Central European Conference in Finance and Economics - CEFE 2017. Herl'any, Słowacja. Košice, Technical University of Košice, pp. 57-69. ISBN: 9788055329062.

Buchelt B.I. (2016), Rosnace znacz̧enie talentów w gospodarce in: Zarządzanie talentami w organizacji. ed. Pocztowski A., Wolters Kluwer SA, Wydanie II, pp.13-37 ISBN 978-83-264-9978-4

Buračas A., Navickas V. (2015). Managing Global Competitiveness: Impact of Talents on Innovations in Baltic States, Taikomoji Ekonomika: Sisteminiai Tyrimai: 2015.9/1, p.13-28. http://dx.doi.org/10.7220/AESR.2335.8742.2015.9.1.1 ISSN 1822-7996 (PRINT), ISSN 23358742 (online)

Chartered Institute of Personnel and Development (CIPD) (2007). Talent Management: Research insight. Retrieved from www.cipd.co.uk

European Commision, EIS 2014-2018. Database, https://ec.europa.eu/growth/industry/innovation/factsfigures/scoreboards_en

Frank F. D., Taylor C. R. (2004). Talent Management: trends that will shape the future, „Human Resource Planning", vol. 27, nr 1, pp. 33-41.

Gorzeń-Mitka I. (2016). Leading Risk Management Determinants of Small and Medium-Sized Enterprises (SMEs): An Exploratory Study in Poland. Eurasian Studies in Business and Economics, 3(1), pp. 289-298.

Jabłoński M. (2015). Istota, funkcje i praktyki zarzqadzania talentami pracowniczymi, in: Talent jako czynnik sukcesu organizacji (Ed.) Springer A., Zeszyty Naukowe Wyższej Szkoły Bankowej w Poznaniu, t. 60, nr 3, Wydawnictwo Wyższej Szkoły Bankowej w Poznaniu, Poznań, pp. 31-48.

Lanvin B., Evans P. (Eds.) (2013). The Global Talent Competitiveness Index 2013. INSEAD Singapore.

Lanvin B., Evans P. (Eds.) (2014). The Global Talent Competitiveness Index 2014. Growing talent for today and tomorrow, Fontainebleau, INSEAD Singapore. 978-2-9522210-7-8

Lanvin B., Evans P. (Eds.) (2015). The Global Talent Competitiveness Index 2015/16. Talent Attraction and International Mobility. Fontainebleau, France. ISBN: 978-2-9522210-9-2,

Lanvin B., Evans P. (Eds.) (2016). The Global Talent Competitiveness Index 2017. Talent and Technology 2017, INSEAD Fontainebleau, France. 
Lanvin B., Evans P. (Eds.) (2017). The Global Talent Competitiveness Index 2018. Diversity for Competitiveness, Fontainebleau, INSEAD France.

Makela K., Bjorkman I., Ehrnrooth M. (2010). How do MNCs establish their talent pools? Influences on individuals' likelihood of being labeled as talent. Journal of World Business, 45, pp.134-142.

ManpowerGroup (2008), Niedobór talentón na rynku pracy. http://www.manpowergroup.pl/raporty-rynkupracy/niedobor-talentow/

ManpowerGroup (2018). „Niedobór talentón”, Jak roz̧wiazać problem niedoboru talentów? Pryygotuj, posyskuj, posiyczaj $i$ przenos, http://www.manpowergroup.com/talent-shortage-explorer/\#.WOjhdvnyjIV $(25.07 .2018)$

ManpowerGroup, (2016), Badanie. Niedobór talentów 2016/2017, http://www.manpowergroup.com/talent-shortage-explorer/\#.WOjhdvnyjIV (01.03.2017)

Mazurkiewicz A. (2013), Makroekonomiczne unarunkowania zarz̨qdzania talentami, Nierówności społeczne a wzrost gospodarczy, nr z. 31, pp. 219-229,

Michaels E., Handfield-Jones H., Axelrod B. (2001). The war for talents, McKinsey \& Company, Inc., Harvard Business School Press, Boston

Mohnen P., Roller L-H. (2005). Complementarities in innovation policy. European Economic Review, 49 (5), pp.14311450.

Navickas V., Kontautiene R. (2013). The Initiatives Of Corporate Social Responsibility As Sources Of Innovations, Verslas: Teorija Ir Praktika Business: Theory And Practice, 2013 14(1), pp. 27-34.

Okręglicka, M., Havierniková K., Mynarzová M., Lemańska-Majdzik A. (2017). Entrepreneurial Intention Creation of Students in Poland, Slovakia and Czechia. Polish Journal of Management Studies. Vol. 15, Issue 2, pp. 162-172.

Pachura, A. (2017). Innovation and change in networked reality. Polish Journal of Management Studies, vol. 15, nr 2, pp. 173-182. [online]. http://www.pjms.zim.pcz.pl/files/Innovation-andChange-in-Networked-Reality.pdf

Serban A., Andanut M. ( 2014 ). Talent Competitiveness and Competitiveness through Talent, Procedia Economics and Finance 16, 21st International Economic Conference 2014, IECS 2014, 16-17 May 2014, Sibiu, Romania pp. 506-511.

Sipa M. (2015). Diversification of Indexes Determining Innovation of Economies - the Visegrad Group Countries, Hradec Economic Days (ed.) Jedlicka P., Vol.5 Hradec Kralove, pp. 174-181.

Sipa M. , Skibiński A., Gorzeń-Mitka I. (2016). Intergenerational Cooperation in the Organization - View from a Gender Perspective. Proceedings of the 1st International Conference Contemporary Issues in Theory and Practice of Management (CITPM 2016), Eds . Okręglicka M. Gorzeń-Mitka I, LemańskaMajdzik A, Sipa M., Skibiński A., Wydawnictwo Wydziału Zarządzania Politechniki Częstochowskiej, Częstochowa 2016, pp.384-389.

Sitek M. (2017). Innovative forms of investments and modern concepts of management of resources in the real estate market, Entrepreneurship and Management, Vol.XVIII, Issue 1, Part 1. 2017, pp. 285-299

Skibiński A., Rączaszek A., (2017) Economic and Demographic Effects of External Migration in Poland and Slovakia Some Aspects. European Journal of Sustainable Development 6, 3, pp.129-140. ISSN: 2239-5938 Doi: 10.14207/ejsd.2017.v6n3p129

Skuza A., Scullion H., McDonnel A. (2013). An analysis of the talent management challenges in a post-communist country: The case of Poland. The International Journal of Human Resource Management, 24, pp.453470.

Smolarek M., Sipa M. (2017). The Impact of CSR on the Competitive Position of Small and Medium Enterprises, Sustainability and Scalability of Business. Theory and Practice (Ed.) Jabtonski A., Business Issues, Competition and Entrepreneurship, Nova Science Publishers, New York, pp. 267-278.

Sullivan J., Wong W., Adusmilli D., Albert A., Blazey L., Huggett M., Parkin J. (2010). Deal or No Deal: An Exploration of the Modern Employment Relationship, The Work Foundation,

Ścibiorek Z. (2004). Ludrie - cenny kapitat organizacji, Wydawnictwo Adam Marszałek, Toruń

Tupá, M. (2013). Talent Management In: Innovation Processes in Orgnizations, Eds. Masárová T., Strunz H., Vojtovič. Wien/Berlin: MERCUR VERLAG, p. 255-276.

Turner P., Tansley C., Foster C., Harris L., Stewart J., Sempik A., Williams H. (2007). Talent: Strategy, Management, Measurement, London, p. XI. 